\title{
LINGKUNGAN HIDUP STRATEGIS TERHADAP PERENCANAAN TATA RUANG KABUPATEN BOLAANG MONGONDOW TAHUN 2011-2030
}

\section{ENVIRONMENTAL STRATEGY ON SPATIAL PLANNING IN BOLAANG MONGONDOW REGENCY YEAR 2011-2030}

\author{
Alex A. Lepa1), Bobby J.V. Polii2) dan Jailani Husain2) \\ 1)Prodi Kimia Jurusan PMIPA FKIP Universitas Cenderawasih Jayapura Papua_99351 \\ E-mail: lepa_alex@yahoo.com (Hp: 085657413866). \\ 2)Fakultas Pertanian Universitas Sam Ratulangi Manado_95115
}

\begin{abstract}
Strategic Environmental Assessment (SEA) can be done to ensure that the preparation of policy, planning and program (PPP) on spatial plan draft of Bolaang Mongondow Regency have included the sustainable development. The purpose of this study was (1) to asses whether the PPP have included the linkage, balance, and fairness principles. (2) to identify the environmental impact caused by implementing PPP defined in the Bolmong's spatial plan. (3) to find out measures in mitigating negative impacts resulting from PPP. The study was performed using quick appraisal approach by means of matrix analysis, expert judgements, secondary data, field survey, and literature. The result revealed that the score of PPP regarding linkage principle was very good (84.24\%) as well as balance principle good (79.59\%). The fairness principle and SEA principle were very good as well which were $(83.72 \%)$, (82.52\%) respectively. Identified nine issues of sustainable development resulted negative and positive impact. This study implied that mitigating negative impacts could be achieved by integrating SEA principles to articles that not fully considering SEA.
\end{abstract}

Keywords: SEA values, negative impact, KRP

\begin{abstract}
ABSTRAK
Kajian Lingkungan Hidup Strategis (KLHS) dapat dilakukan untuk memastikan bahwa penyusunan KRP dalam Raperda RTRW Kabupaten Bolmong telah mengintegrasikan pembangunan berkelanjutan. Tujuan penelitian ini ialah untuk: (1) mengidentifikasi apakah KRP yang tertuang dalam RTRW Kabupaten Bolmong telah memiliki asas keterkaitan, keseimbangan, dan asas keadilan. (2) mengidentifikasi dampak yang dapat terjadi pada lingkungan hidup akibat dari KRP yang sudah ditetapkan dalam raperda RTRW Kabupaten Bolmog. (3). merekomendasikan upaya mitigasi dampak negatif akibat dari KRP yang tertuang dalam Raperda RTRW Kabupatan Bolmong. Metodologi dalam penelitian ini menggunakan pendekatan penilaian cepat (quick appraisal) dengan metode analisis matriks, pertimbangan pakar, analisis data sekunder, survei lapangan, dan kajian pustaka. Hasil penelitian, yakni: (1). KRP pada RTRW kabupaten Bolaang Mongondow telah memiliki nilai asas keterkaitan $84,24 \%$, asas keseimbangan $79,59 \%$, asas keadilan $83,72 \%$, dengan nilai KLHS sebesar $82,52 \%$. (2). Teridentifikasi 9 isu pembangunan berkelanjutan berdampak negatif, dan 1 isu berdampak positif. (3) Cara memitigasi dampak negatif, yakni mengintegrasikan nilai-nilai KLHS untuk pasal-pasal yang belum sepenuhnya memiliki nilai-nilai KLHS atau berpotensi sedang sampai amat sangat besar berdampak negatif terhadap lingkungan.
\end{abstract}

Kata Kunci: Nilai KLHS, Dampak Negatif, KRP 


\section{PENDAHULUAN}

Pembangunan berkelanjutan adalah upaya sadar dan terencana yang memadukan aspek lingkungan hidup, sosial, dan ekonomi ke dalam strategi pembangunnan untuk menjamin keutuhan lingkungan serta keselamatan, kemampuan, kesejahteraan, dan mutu hidup generasi masa kini dan generasi masa depan (Anonimous, 2009). Dokumen-dokumen PBB, terutama dokumen hasil World Summit 2005, yang menyebutkan tiga pilar pendukung pembangunan berkelanjutan yang saling terkait, yakni lingkungan, sosial, dan ekonomi (Anonimous, 2011). Keseimbangan antara lingkungan dengan sosial akan menghasilkan ketahanan hidup, keseimbangan antara lingkungan dengan ekonomi akan menjamin kehidupan terus berlangsung, dan keseimbangan antara sosial dan ekonomi akan meberikan keadilan. Keseimbangan antara lingkungan hidup, sosial, dan ekonomi akan menjamin ketahanan hidup dapat berlangsung terusmenerus secara adil. Mengutamakan lingkungan dalam setiap proses pembangunan, akan memberikan jaminan yang pasti dalam pelaksanaan pembangunan berkelanjutan. Kebijakan, Rencana, dan Program (KRP) yang disusun dalam Rencana Tata Ruang Wilayah (RTRW) harus mengintegrasikan pembangunan berkelanjutan untuk mencegah/mengurangi dampak negatif.

Rencana Tata Ruang Wilayah Nasional yang selanjutnya disebut RTRWN adalah arahan kebijakan dan strategi pemanfaatan ruang wilayah negara (Anonimous, 2008). Rencana tata ruang wilayah (RTRW) Kabupaten mengacu pada RTRW Nasional dan Provinsi, yang secara hierarki (Anonimous, 2007) dapat dilihat pada Gambar 1.

RTRW berisi tentang Kebijakan, Rencana dan Program (Anonimous, 2011). Kebijakan adalah arah/tindakan yang diambil oleh Pemerintah pusat/ daerah untuk mencapai tujuan. Rencana adalah hasil suatu proses untuk menentukan tindakan masa depan yang tepat, melalui urutan pilihan, dengan memperhitungkan sumber daya yang tersedia. Program adalah instrumen kebijakan yang berisi satu atau lebih kegiatan yang dilaksanakan oleh instansi pemerintah/lembaga untuk mencapai sasaran dan tujuan serta memperoleh alokasi anggaran, atau kegiatan masyarakat yang dikoordinasikan oleh instansi pemerintah. Kajian Lingkungan Hidup Strategis (KLHS), dapat dilakukan untuk memastikan bahwa penyusunan KRP dalam Raperda RTRW Kabupaten Bolaang Mongondow (Bolmong) telah mengintegrasikan pembangunan berkelanjutan.

Menurut Therievel et.al. (1992) bahwa KLHS adalah proses yang menyeluruh, sistematis dan terencana untuk menilai pengaruh terhadap lingkungan akibat dari kebijakan, rencana, program, dan lain-lain, termasuk dokumen yang memuat temuan evaluasi dan dipakai untuk menghasilkan keputusan yang memiliki akuntabilitas publik. Sadler and Verheem (1996) mendefinisikan bahwa KLHS adalah proses yang sistematis untuk menilai pengaruh terhadap lingkungan dari suatu usulan kebijakan, rencana, atau program sebagai upaya untuk menjamin bahwa pengaruh tersebut telah dipertimbangkan dan dimasukan sedini mungkin dalam proses pengambilan keputusan bersamaan dengan pertimbangan sosial dan ekonomi. Definisi KLHS menurut DEAT and CSIR (2000) adalah proses untuk mengintegrasikan konsep berkelanjutan dalam pengambilan keputusan yang strategis. KLHS adalah rangkaian analisis yang sistematis, menyeluruh, dan partisipatif untuk memastikan bahwa prinsip pembangunan berkelanjutan telah menjadi dasar dan terintegrasi dalam pembangunan suatu wilayah dan/atau kebijakan, rencana, dan/atau program (Anonimous, 2009).

Dua faktor utama penyebab munculnya KLHS diperlukankan saat ini di berbagai belahan dunia ialah : (1) KLHS mengatasi kelemahan dan keterbatasan AMDAL, dan (2) KLHS merupakan instrumen yang lebih efektif untuk mendorong pembangunan berkelanjutan (Briffetta et.al., 2003). Pelaksanaan KLHS dapat dilakukan pada saat penyusunan atau evaluasi terhadap RTRW, RPJP, RPJM, dan/atau KRP (Anonimous, 2009). Tiga jenis KLHS ialah: sebagai instrumental, transformatif, dan sebagai substansi (Salder, 2005). Menurut Atiek Koesrijanti, dkk. (2007) bahwa RTRWN, RPJPN, RPJMN, RTRW Propinsi/Kabupaten/Kota, RPJPD, dan RPJMD ialah wajib KLHS tanpa proses penapisan. 


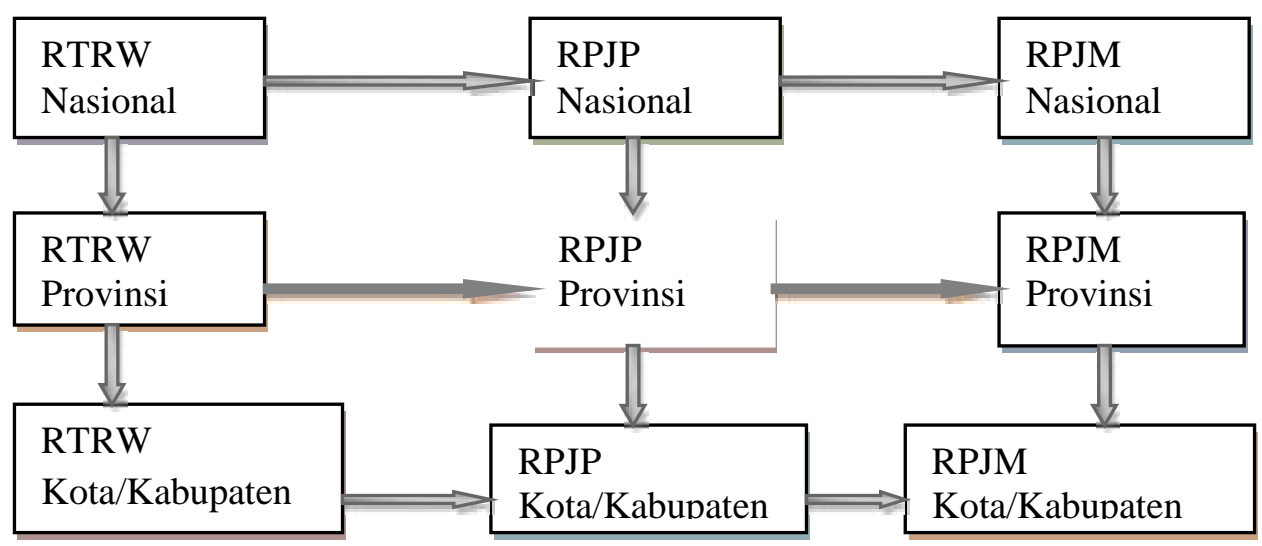

Gambar 1. Strukur RTRW, RPJP, dan RPJM

(Figure 1. Spatial structure of, RPJP, and RPJM)

Metode analisis untuk pendekatan penilaian cepat (quick appraisal) dan pendekatan penilain semi rinci (semi-detailed assessment) ialah: metode analisis pertimbangan ahli, metode analisis matriks, dan metode analisis spasial. Kajian/penilain yang rinci dapat menggunakan beberapa metode seperti: metode diagram jejaring dan sistem, model dan simulasi, analisis multi kriteria, skenario, dan metode delphi (KLH, 2010; Dusik, 2009). Penilaian ahli yang terogranisir dengan baik tidak berarti menebak (ODPM, 2003) dan metode ini memerlukan penjelasan yang jelas terhadap asumsi yang mendasari penilaian tersebut, misalnya kapan pengaruhnya akan terasa dan penyebabnya apa. Sebagian besar dari praktek KLHS adalah berdasarkan penilaian ahli dan hal ini merupakan metode penilaian yang sah (Dusik, 2009).

KLHS merupakan salah satu instrument untuk mencegah pencemaran/kerusakan lingkungan hidup yang wajib dilaksanakan oleh Pemerintah untuk memastikan bahwa prinsip pembangunan berkelanjutan telah menjadi dasar dan terintegrasi dalam pembangunan suatu wilayah atau kebijakan, rencana, dan program (Anonimous, 2009). PERMEN-LH Nomor 27 tahun 2009, meyebutkan bahwa nilai penting KLHS ialah keterkaitan (interdependence), keseimbangan (equilibrium), keadilan (justice). Pelaksanaan KLHS dapat dilakukan dalam penyusunan atau evaluasi RTRW Kabupaten Bolaang Mongondow. Mekanisme pelaksanaan KLHS ialah: (1) pengkajian/evaluasi nilai-nilai KLHS dan pengaruh/dampak KRP terhadap kondisi lingkungan hidup di suatu wilayah; (2) perumusan alternatif penyempurnaan KRP; (3) rekomendasi perbaikan KRP yang mengintegrasikan nilai-nilai KLHS dalam Raperda RTRW kabupaten Bolaang Mongondow. Kerusakan sumber daya alam dan pencemaran lingkungan akan lebih efektif dan efisien untuk dicegah bila sejak proses formulasi KRP telah dipertimbangkan masalah lingkungan hidup dan ancaman terhadap pembangunan berkelanjutan dengan mengintergrasikan nilai-nilai KLHS. KRP yang dituangkan dalam Raperda RTRW 2011-2030 Kabupaten Bolaang Mongondow oleh pemerintah daerah dan masyarakat, berpotensi menimbulkan dampak/pengaruh terhadap lingkungan hidup.

Berbagai pembangunan telah dilakukan di Kabupaten Bolang Mongondow untuk meningkatkan kesejahteraan masyarakat, namun hingga saat ini masih banyak masyarakat yang belum menikmatinya secara adil dan merata. Hal ini dapat terlihat diantaranya ialah meningkatnya jumlah penduduk yang tidak memiliki lahan pertanian, terjadi bencana banjir yang banyak menyebabkan kerugian harta benda, dan banyak sungai dan kolam yang menjadi dangkal dan tertutup atau hilang. Peristiwa lain yang terjadi ialah penambangan liar yang tidak memperhatikan kelestarian lingkungan, alih fungsi hutan lindung menjadi sawah irigasi dan pemukiman, pencemaran, serta berkurangnya keanekaragaman hayati. Kondisi ini dapat terjadi dengan cepat sebagai akibat dari pelaksanaan KRP yang tertuang dalam RTRW Kabupaten Bolaang Mongondow yang belum mengintegrasikan secara utuh tentang nilai-nilai KLHS. 
Penelitian ini bertujuan untuk: (1) identifikasi dan analisis apakah KRP yang tertuang dalam RTRW Kabupaten Bolaang Mongondow telah memiliki asas keterkaitan, keseimbangan, dan asas keadilan. (2) identifikasi dan analisis dampak yang dapat terjadi pada lingkungan hidup akibat dari KRP yang sudah ditetapkan dalam Raperda RTRW Kabupaten Bolaang Mongondow. (3) Merekomendasikan upaya mitigasi dampak negatif akibat dari KRP yang tertuang dalam Raperda RTRW Kabupatan Bolaang Mongondow. Berdasarkan kajian di atas, maka peneliti telah melakukan penelitian terhadap KRP pada Raperda RTRW Kabupaten Bolaang Mongondow untuk mengevaluasi nilai-nilai KLHS dan dampak/pengaruh yang dapat timbul serta menyusun dan merekomendasikan KRP yang dapat mencegah atau mengurangi dampak negatif.

\section{METODE PENELITIAN}

Penelitian ini dilaksanakan di Kabupaten Bolaang Mongondow Provinsi Sulawesi Utara. Waktu pelaksanaan dimulai pada awal Bulan Juni 2011 dan selesai pada akhir Bulan Oktober 2011.

Penelitian ini termasuk dalam penelitian deskriptif dengan analisis dokumen (documentary analysis), yaitu penelitian yang dilakukan terhadap informasi yang didokumentasikan dalam rekaman, baik gambar, suara, tulisan, atau lain-lain bentuk rekaman (Arikunto Suharsimi, 2009).

Materi yang digunakan dalam penelitian ini ialah keseluruhan KRP yang terdapat dalam Raperda RTRW Kabupaten Bolaang Mongondow, mulai dari pasal 2 sampai dengan pasal 66, tidak termasuk lampiran. Variabel penelitian ini ialah kebijakan, rencana, program, nilai-nilai KLHS, dan dampak/pengaruh dari KRP dalam Raperda RTRW Kabupaten Bolaang Mongondow.

\section{Analisis Data}

Proses analisis data dalam penelitian ini, menggunakan pendekatan analisis penilaian cepat (quick appraisal) dengan metode analisis matriks yang direkomendasikan berdasarkan Surat Edaran Bersama (SEB) Menteri Dalam Negeri dan Menteri Negara Lingkungan Hidup Republik Indonesia dengan nomor: 660/5113/SJ dan nomor: 04/ MENLH/12/2010. Formulasi model analisis KLHS raperda RTRW Kabupaten Bolaang Mongondow dapat dilihat pada Gambar 2.

\section{HASIL DAN PEMBAHASAN}

\section{Analisis Nilai Asas Keterkaitan, Keseimbangan dan Keadilan serta Nilai Rata-rata KLHS}

Berdasarkan data hasil analisis terhadap KRP dalam Raperda RTRW Kabupaten Bolaang Mongondow, menunjukan bahwa nilai asas keterkaitan, keseimbangan, dan asas keadilan, masingmasing memiliki nilai $84,24 \%$; 79,59\%; dan $83,72 \%$; dengan nilai rata-rata KLHS sebesar $82,52 \%$. Jika dihubungkan dengan kriteria penilaian, maka nilai asas keterkaitan, asas keadilan, dan nilai rata-rata KLHS termasuk dalam kategori sangat baik (81\%-100\%), sedangkan nilai asas keseimbangan masuk dalam ketegori baik $(61 \%$ $80 \%$ ), akan tetapi hal ini masih perlu perbaikan di beberapa pasal yang belum sepenuhnya mengintegrasi nilai KLHS. Secara keseluruhan nilai ratarata KLHS sudah sangat baik, hal ini disebabkan karena Raperda RTRW Kabupaten Bolaang Mongondow telah melakukan konsultasi perbaikan dengan Pemerintah Provinsi SULUT, dimana sebelumnya Raperda RTRW berisi 130 pasal, dan setelah melakukan tahapan konsultasi menjadi 66 pasal.

Hasil analisis nilai rata-rata KLHS ialah $82,52 \%$ yang merupakan penggabungan dari nilai asas keterkaitan, keseimbangan, dan asas keadilan yang dirata-ratakan. Pasal-pasal yang berkontribusi pada nilai rata-rata KLHS ialah pasal 2, 3, 4, 23 , secara berturut-turut $53,3 \%, 54 \%, 37,9 \%$, $73,3 \%$, pasal 5-11, 13-15, 24, 26-28, 31 memberikan kontribusi $93,3 \%$ untuk tiap pasal, pasal 32 (86,7\%), dan pasal 12, 16-22, 25, 29-30, 33-60, 62-63, 64, 66 masing-masing 100\%, sedangkan pasal 61 dan 65 hanya $0 \%$. Pasal-pasal yang masih perlu perbaikan dan penambahan KRP ialah pasal 2, 3, dan 4 yang terkait dengan tujuan, kebijakan dan strategi, serta pasal 23 mengenai kawasan rawan bencana alam. Perbaikan KRP juga dilakukan terhadap pasal 5-11 dan 13-15 yang berhubungan dengan rencana struktur ruang, pasal 24 mengenai kawasan budidaya, pasal 26-28 tentang kawasan pertanian, perikanan, dan per- 
tambangan, serta pasal 31-32 yang menyangkut kawasan permukiman dan peruntukan lainnya. Kawasan strategis provinsi (pasal 35) dan kawasan strategis kabupaten (36) perlu mendapat perbaikan/penambahan KRP. Evaluasi terhadap KRP dalam Raperda RTRW Kabupaten Bolaang Mongondow, menunjukan bahwa aspek kebijakan pada pasal 2 mengenai tujuan dan pasal 3 terkait dengan kebijakan, masih dalam kategori cukup, sedangkan pasal 4 yang menyangkut strategi, berada pada kategori kurang. Hal ini membuktikan bahwa pada tingkat kebijakan masih lemah dalam mengintegrasikan nilai-nilai KLHS.

\section{Dampak KRP dalam Raperda RTRW Kabupaten Bolaang Mongondow Terhadap Isu Pembangunan Berkelanjutan}

Hasil identifikasi isu pembangunan berkelanjutan di Kabupaten Bolaang Mongondow, terdapat 10 isu yang terdiri atas: alih fungsi lahan, bencana alam, penurunan mutu/jumlah SDA, kemiskinan, konflik sosial, kesehatan/keselamatan, perubahan iklim, berkurangnya keanekragaman hayati, pencemaran, dan pendangkalan atau hilangnya sungai/kolam/danau. Isu pembangunan berkelanjutan, diidentifikasi berdasarkan kondisi nyata yang ada di Kabupaten Bolaang Mongondow berdasarkan survei lapangan dan analisis data sekunder pada Bolmong Dalam Angka 2011.

Berdasarkan hasil indentifikasi dugaan dampak/pengaruh, menunjukan bahwa dari 10 isu pembangunan berkelanjutan, terdapat 9 isu yang berdampak negatif, yakni: (a) alih fungsi lahan $(69 \%)$, (b) bencana alam (21\%), (c) penurunan mutu/jumlah SDA (1\%), (d) konflik sosial (47\%), (e) kesehatan/keselamatan (24\%), (f) perubahan iklim $(13 \%),(\mathrm{g})$ berkurangnya keanekragaman hayati $(21 \%)$, (h) pencemaran (28\%), dan (i) pendangkalan atau hilangnya sungai/kolam/danau (22\%). Dilihat dari kategori dampak negatif, alih fungsi lahan termasuk dalam kategori buruk (berdampak besar), dan konflik sosial berkategori kurang baik (berdampak sedang). Bencana alam, kesehatan/ keselamatan, berkurangnya keanekaragaman hayati, pencemaran, dan pendangkalan atau hilangnya sungai/kolam/danau, termasuk dalam kategori baik (berdampak agak sedang), perubahan iklim berkategori sangat baik (berdampak kecil), dan penurunan mutu/jumlah SDA berkategori amat sangat baik (berdampak sangat kecil). Rata-rata nilai dampak negatif kumulatif untuk 9 (sembilan) isu pembangunan berkelanjutan yang teridentifikasi yakni sebesar $24,6 \%$, nilai dampak negatif kumulatif ini termasuk dalam kategori baik (berdampak agak sedang). Nilai dampak negatif kumulatif ini sangat perlu untuk diwaspadai karena dapat berpotensi menimbulkan dampak yang lebih besar terhadap lingkungan, jika tidak dilakukan perbaikan/ penambahan KRP serta pengendalian secara ketat melaui penegakan hukum yang lebih baik.

Jumlah dampak negatif dan positif yang dapat teridentifikasi dengan metode analisis matriks untuk tiap isu pembangunan berkelanjutan ialah: alih fungsi lahan (84\%), bencana alam (73\%), penurunan mutu/jumlah SDA (59\%), kemiskinan $(83 \%)$, konflik sosial $(81 \%)$, kesehatan/keselamatan $(87 \%)$, perubahan iklim (66\%), keanekaragaman hayati $(69 \%)$, pencemaran $(79 \%)$, dan pendangkalan atau hilangnya sungai/kolam/ danau (73\%). Rata-rata dari penggabungan nilai dampak positif dan negatif ialah sebesar $75,4 \%$. Nilai rata-rata ini dapat memberikan gambaran bahwa metode analisis matriks termasuk metode analisis yang baik untuk menidentifikasi dampak yang mungkin dapat timbul sebagai akibat dari KRP pembangunan yang diusulkan. Secara keseluruhan, KRP pada RTRW Kabupaten Bolaang Mongondow berpotensi mengatasi keanekaragaman hayati sebesar $48 \%$.

\section{Kebijakan, Rencana, dan Program (KRP)}

Nilai-nilai KLHS untuk asas keterkaitan, keseimbangan, dan keadilan pada aspek kebijakan dalam raperda RTRW Kabupaten Bolaang Mongondow masih berkategori cukup (41\%-60\%). Hal ini terlihat dengan jelas bahwa pada tingkat kebijakan yang tertuang dalam RTRW Kabupaten Bolaang Mongondow belum sepenuhnya mengintegrasikan nilai-nilai KLHS atau pembangunan berkelanjutan. 


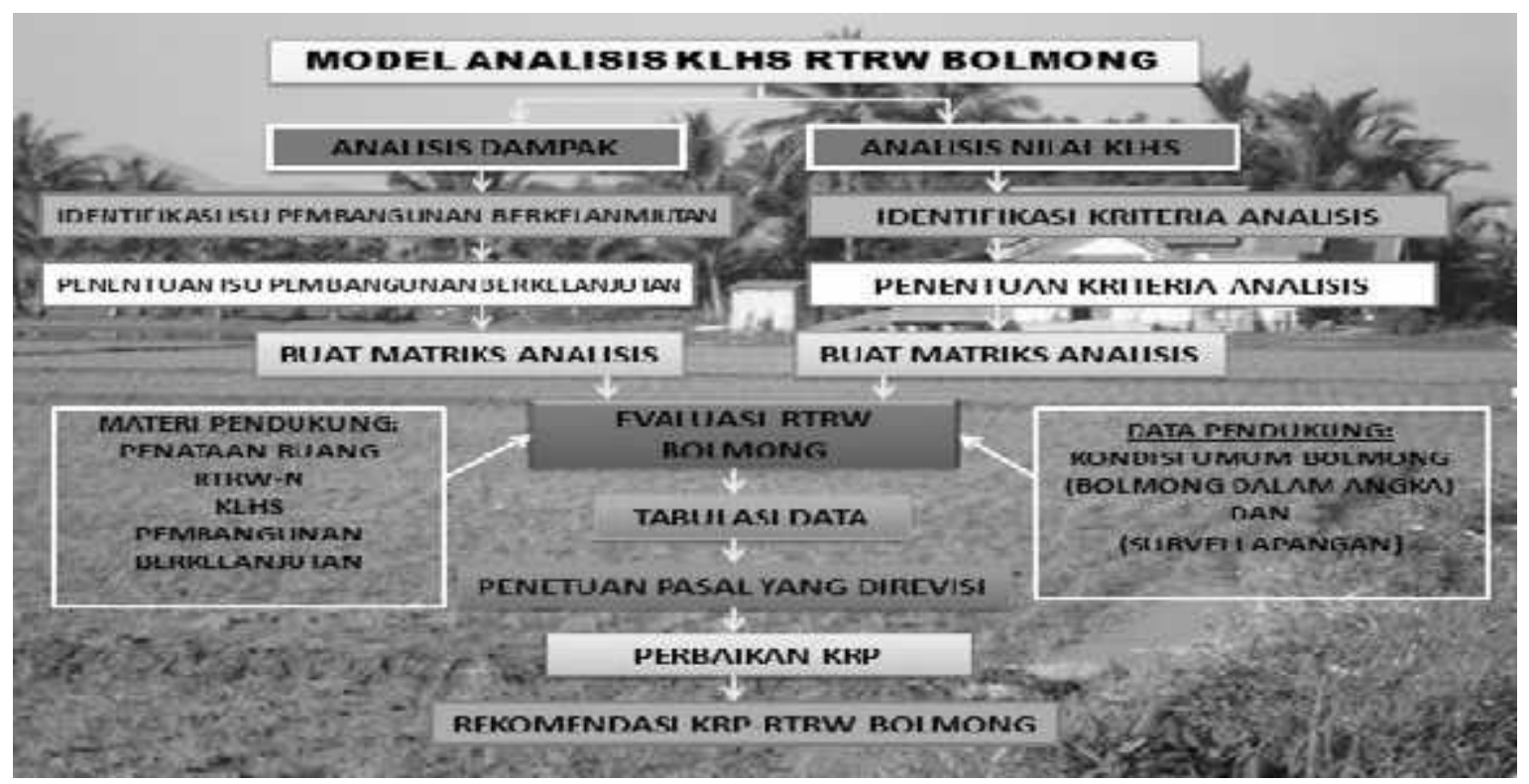

Gambar 2. Formulasi Model Analisis KLHS RTRW Kabupaten Bolmong

(Figure 2. Spatial Analysis Model Formulation KLHS Bolmong District)

Kebijakan yang terkait dengan asas keterkaitan, keseimbangan, dan keadilan sangat perlu untuk direvisi, sehingga dapat menjamin pembangunan berkelanjutan di Kabupaten Bolaang Mongondow.

Kebijakan yang berpotensi menimbulkan dampak negatif ialah: peningkatan pertumbuhan ekonomi, pengembangan kawasan permukiman, dan prasarana-sarana. Analisis isu-isu pembangunan berkelanjutan terhadap kebijakan pada raperda RTRW Kabupaten Bolaang Mongondow, menunjukkan bahwa kebijakan berpotensi menimbulkan dampak negatif, yakni: (1) berpotensi terjadi konflik sosial sebesar $64,88 \%$; (2) 50\% mendorong alih fungsi lahan, (3) berpeluang terjadi pencemaran sebesar $31,25 \%$; (4) 18,75\% dapat menyebabkan terjadinya pendangkalan, penyempitan sampai hilangnya sungai/kolam/danau; (5) $15,63 \%$ berpotensi menimbulkan bencana alam, gangguan kesehatan/keselamatan, dan berkurang atau punahnya keanekaragamana hayati; (6) beresiko terjadi perubahan iklim sebesar 12,5\%; dan (7) tidak teridentifikasi adanya penurunan mutu/jumlah sumber daya alam dan kemiskinan. Terlihat dengan jelas bahwa kebijakan pada RTRW Kabupaten Bolaang Mongondow berpotensi tertinggi terjadi konflik sosial dan alih fungsi lahan. Kebijakan yang tertuang pada RTRW Kabupaten Bolaang Mongondow dapat mengatasi kemiskinan dan kesehatan/keselamatan masing-masing sebesar $75 \%$, sedangkan $56,25 \%$ dapat mencegah terjadinya bencana alam, meningkatkan mutu/jumlah sumber daya alam, mencegah terjadinya perubahan iklim, dan mengatasi pendangkalan, penyempitan, serta hilangnya sungai/kolam/danau. Hal yang lain ialah mencegah terjadinya pencemaran, mempertahan/meningkatkan keanekaragaman hayati, mengatasi alih fungsi lahan, dan mengatasi konflik sosial masing-masing sebesar $50 \%$; $43,75 \%$; $28,13 \%$; dan $25 \%$.

Rencana yang tertuang pada raperda RTRW Kabupaten Bolaang Mongondow, hasil evaluasi menunjukan bahwa nilai asas keterkaitan telah mencapai $100 \%$, sedangkan untuk asas keseimbangan dan keadilan masing-masing $87,78 \%$ dan $98,89 \%$. Asas keseimbangan dan keadilan yang terkait dengan rencana pada raperda RTRW Kabupaten Bolaang Mongondow masih perlu untuk diperbaiki atau diberikan tambahan rencana untuk menjamin pembangunan berkelanjutan.

Rencana struktur ruang dan rencana pola ruang yang terkait dengan kawasan budidaya berpotensi menimbulkan dampak negatif. Hasil analisis rencana pada raperda RTRW Kabupaten Bolaang Mongondow berpotensi menimbulkan dampak negatif tertinggi untuk mendorong alih fungsi lahan sebesar $71,05 \%$, dan berpeluang me- 
nimbulkan konflik sosial sebesar $65,89 \%$. Rencana pada RTRW Kabupaten Bolaang Mongondow dapat juga menimbulkan dampak negatif lain terhadap ligkungan hidup, yakni: mengganggu kesehatan/keselamatan (50\%); berpotensi terjadi pencemaran (47,37\%); berpeluang terjadi bencana alam, turunnya keanekaragaman hayati, dan pendangkalan, penyempitan serta hilangnya sungai/ kolam/danau masing-masing $42,11 \%$; perubahan iklim (23,68\%); dan turunnya mutu/jumlah sumber daya alam (2,63\%). Rencana pada raperda RTRW Kabupaten Bolaang Mongondow, dapat berpeluang untuk mengatasi kemiskinan (94,74\%); kesehatan/ keselamatan (39,47\%); perubahan iklim (34,21\%); keanekaragaman hayati $(31,58 \%)$; mencegah terjadinya bencana alam, pencemaran, dan penyempitan, pendangkalan, serta hilangnya sungai/ kolam/danau, masing-masing sebesar $28,95 \%$; dan mencegah alih fungsi lahan serta konflik sosial masing-masing $15,79 \%$ dan 7,89\%.

Data evaluasi terhadap program yang tertuang pada raperda RTRW Kabupaten Bolaang Mongondow, menunjukkan bahwa nilai-nilai KLHS untuk asas keterkaitan, keseimbangan, dan keadilan masing-masing 93,33\%. Hasil penilaian ini belum sepenuhnya mengintegrasikan nilai-nilai KLHS, disebabkan karena pasal 61 dan 65 tidak teridentifikasi adannya nilai-nilai KLHS, untuk itu pasal 61 dan 65 perlu direvisi atau digabung dengan pasal yang lain.

Program pemanfaatan ruang wilayah Kabupaten Bolaang Mongondow berpedoman pada rencana struktur ruang dan pola ruang (pasal 37 ayat 1 Raperda RTRW Kabupaten Bolaang Mongondow, 2011). Program-program yang berpotensi menimbulkan dampak negatif ialah: program pengembangan hutan produksi, pertanian, perikanan, pertambangan, perindustrian, pariwisata, dan permukiman. Berdasarkan hasil analisis, diketahui bahwa program pada raperda RTRW Kabupaten Bolaang Mongondow dapat berdampak negatif dan positif terhadap lingkungan hidup. Dampak negatif akibat dari program yang tertuang pada RTRW Kabupaten Bolaang Mongondow ialah berpotensi mendorong alih fungsi lahan sebesar $86,67 \%$, dan $23,33 \%$ berpeluang menimbulkan konflik sosial.
Hasil analisis asas nilai rata-rata KLHS terhadap kebijakan, rencana, dan program dalam RTRW Kabupaten Bolaang Mongondow, secara keseluruhan menunjukan bahwa kebijakan memiliki nilai-nilai KLHS sebesar 42,7\%, rencana $(95,56 \%)$, dan program $(93,3 \%)$. Terlihat dengan jelas bahwa pada aspek kebijakan masih berkategori cukup dalam mengintegrasikan nilai-nilai KLHS yang merupakan indikator dari pembangunan berkelanjutan. Hal ini terbukti bahwa pada tingkat kebijakan dalam raperda RTRW masih belum sepenuhnya mengintegrasikan pembangunan berkelanjutan, sehingga perlu untuk diberikan perbaikan atau penambahan kebijakan yang mengintergrasikan pembangunan berkelanjutan.

Data hasil analisis nilai rata-rata kebijakan, rencana, dan program (KRP) dalam raperda RTRW Kabupaten Bolaang Mongondow terhadap isu pembangunan berkelanjutan, secara keseluruhan dapat dilihat bahwa kebijakan berpotensi menimbulkan dampak negatif sebesar 20,63\% pada lingkungan hidup, dan $52,16 \%$ dapat mengatasi atau mencegah kerusakan lingkungan. Rencana pada RTRW Kabupaten Bolaang Mongondow dapat berpotensi menimbulkan dampak negatif sebesar 38,68\% (berdampak sedang) terhadap lingkungan hidup, dan $36,05 \%$ dapat mengatasi atau mencegah kerusakan lingkungan. Hal ini perlu mendapatkan perhatian yang sangat serius terhadap rencana yang tertuang dalam RTRW Kabupaten Bolaang Mongondow, karena berpotensi lebih besar untuk merusak lingkungan hidup dari pada mengatasi atau mencegahnya. Program yang tertuang pada RTRW Kabupaten Bolaang Mongondow berpotensi menimbulkan dampak negatif terhadap lingkungan hidup se-besar $11 \%$ (berdampak kecil), dan 68\% dapat mengatasi atau mencegah kerusakan lingkungan. Hal ini sangat baik karena program pemanfaatan ruang yang tertuang dalam RTRW Kabupaten Bolaang Mongondow disertai dengan program pengendalian pemanfaatan ruang, kelembagaan, peran masyarakat, ketentuan lain, ketentuan peralihan, dan ketentuan penutup yang diatur dalam pasal 39-66 raperda RTRW Kabupaten Bolaang Mongondow. Adanya program pengendalian pemanfaatan ruang, belum sepenuhnya menjamin pelaksanaan pro- 
gram pemanfaatan ruang secara baik, akan tetapi hal ini perlu mendapat perhatian bersama dari seluruh masyarakat dan pemerintah untuk saling mengawasi dalam pemanfaatan ruang. Meningkatkan sumber daya alam dengan memperhatikan kelestarian lingkungan hidup, memberikan kesempatan yang sama kepada masyarkat untuk memperoleh pengetahuan, ketrampilan, dan permodalan dalam memenfaatkan ruang merupakan hal yang sangat penting untuk melaksanakan pembangunan berkelanjutan.

\section{Mencegah/mengurangi Dampak Negatif dari KRP Dalam RTRW Kabupaten Bolaang Mongondow Terhadap Isu Pembangunan Berkelanjutan}

Mencegah adalah merintangi, melarang, atau mengikhtiarkan supaya jangan terjadi. Mengurangi adalah mengambil atau memotong sebagian, atau menjadikan berkurang. Mengikhtiarkan supaya tidak terjadi dampak negatif ialah mencegah dampak negatif. Mengurangi dampak negatif adalah memperkecil atau menjadikan dampak negatif berkurang. Untuk mencegah/mengurangi dampak negatif yang dapat ditimbulkan oleh KRP yang tertuang dalam RTRW Kabupaten Bolaang Mongondow terhadap isu pembangunan berkelanjutan, maka salah satu alternatif yang dapat dilakukan ialah perbaikan atau penambahan KRP menjadi lebih baik dengan mengintegrasikan nilainilai KLHS. Nilai-nilai KLHS yang perlu diintergrasikan dalam KRP adalah asas keterkaitan, keseimbangan, dan asas keadilan.

Asas keterkaitan yang penting untuk diintegrasikan dalam KRP ialah keterkaitan antar lokal dan global, antar daerah/wilayah, antar sektor, antar komponen/unsur, dan antar variabel. Keterkaitan lokal dan global ialah menghubungkan antara skala/ukuran yang lebih kecil dengan skala yang lebih luas. Hubungan antara desa dengan kecamatan, kecamatan dengan kota kabupaten merupakan contoh keterkaitan antar daerah/wilayah. Menghubungkan antara bidang pertanian dengan bidang perikanan, bidang perikanan dengan bidang perhubungan, bidang pendidikan dengan bidang pertambangan ialah contoh keterkaitan antar sektor. Mengaitkan antara komponen tanah dengan udara, komponen air dengan tumbuh-tumbuhan ialah contoh keterkaitan antara komponen/unsur. Mengkorelasikan antara iklim dengan musim tanam, kesuburan tanah dengan hasil panen, interaksi sosial dengan kecanggihan alat telekomunikasi ialah contoh-contoh keterkaitan antar variabel.

Asas keseimbangan yang harus diintegrasikan pada KRP dalam RTRW kabupaten Bolaang Mongondow ialah tiga keseimbangan penting yaitu antara lingkungan hidup (yang menjadi pertimbangan utama), sosial (kedua), dan ekonomi (ketiga). Setiap pemanfaatan ruang, lingkungan hidup selalu diberikan prioritas utama untuk diperhatikan dengan serius agar dapat mendukung proses kehidupan dengan baik. Disamping itu ada keseimbangan lain, yakni: keseimbangan antara kepentingan pembangunan pusat dan daerah serta keseimbangan antara jangka pendek dan jangka panjang. Keseimbangan pembangunan pusat dan daerah yang dimaksud adalah terciptanya keseimbangan antara pembangunan di desa, kota kecamatan, dan kota kabupaten. Keseimbangan antara jangka pendek dengan jangka panjang ialah memperhatikan kebutuhan kondisi saat ini dan kondisi yang akan datang, artinya kehidupan generasi saat ini terjamin dengan baik dan juga generasi yang akan datang.

Asas keadilan merupakan salah satu nilai penting dari KLHS yang banyak diperjuangkan orang sebelum mendapatkan atau menduduki kursi kekuasaan. Setelah menduduki kursi kekuasaan banyak orang mulai meninggalkan asas keadilan, dan hal ini dapat memberikan dampak kemiskinan yang tak akan ada habisnya di dunia ini. Kondisi ini akan dapat berlangsung terus jika masyarakat tidak berusaha untuk memperoleh pengetahuan, ketrampilan, dan modal untuk mengembangkan usaha. Kurang pengetahuan, ketrampilan, dan modal serta kesempatan untuk berusaha menjadi penyebab utama keadilan tidak dapat diwujudkan dengan baik. Masyarakat harus mendapatkan kesempatan yang sama untuk memperoleh pengetahuan, ketrampilan, dan modal dalam memanfaatkan ruang di wilayah Kabupaten Bolaang Mongondow. Diharapkan dengan mengintegrasikan asas keadilan pada KRP dalam RTRW Kabupaten Bolaang 
Mongondow, masyarakatnya akan dapat menikmati keadilan yang sejati.

\section{KLHS dan Dampak KRP di Wilayah Perbatasan Antar Daerah}

Kawasan perbatasan antar daerah memi-

liki isu-isu strategis yang terkait dengan antisipasi bencana alam, perubahan iklim, pencemaran lintas batas, dan perpindahan sumber daya satwa. Isuisu yang terdapat di kawasan perbatasan perlu ditangani secara terpadu guna mensinergikan berbagai sumber daya yang dikerahkan untuk menangani berbagai isu dalam rangka penguatan dan peningkatan kesejahteraan masyarakat di wilayah tersebut.

Persoalan-persoalan lingkungan yang muncul dapat disebabkan oleh kegiatan yang berada di wilayah daerah tetangga, akan tetapi dampaknya terjadi di wilayah Kabupaten Bolaang Mongondow atau sebaliknya. Hal ini menunjukan bahwa masalah lingkungan hidup tidak dibatasi oleh wilayah administrasi dan karakteristik ekosistem daerah tetangga. Terjadi kerusakan di wilayah Kabupaten Bolaang Mongondow, tidak menutup kemungkinan akan menimbulkan dampak di daerah tetangga atau sebaliknya. Permasalahan ini perlu untuk ditangani dengan baik secara dini melalui perumusan kebijakan, rencana, dan program bersama di wilayah perbatasan. Jika hal ini dibiarkan, akan menjadi masalah yang berkepanjangan dan akan merugikan daerah tetangga atau sebaliknya.

\section{KESIMPULAN}

Kebijakan, Rencana, dan Program pada RTRW Kabupaten Bolaang Mongondow telah memiliki nilai asas keterkaitan (sangat baik), asas keseimbangan (baik), asas keadilan (sangat baik), dengan nilai rata-rata KLHS sangat baik, serta berpotensi untuk mempertahankan keanekaragaman hayati sebesar $48 \%$ (cukup berpotensi).

Isu-isu pembangunan berkelanjutan yang dikorelasikan dengan KRP pada pasal 2-66 RTRW Bolaang Mongondow, masing-masing teridentifikasi 9 isu berdampak negatif dan 1 isu berdampak positif. Kesembilan isu ini yakni: (a) alih fungsi lahan (69\%); (b) bencana alam (21\%); (c) penurunan mutu/jumlah SDA (1\%); (d) konflik sosial (47\%); (e) kesehatan/ keselamatan (24\%); (f) perubahan iklim (13\%); (g) berkurangnya keanekaragaman hayati (21\%); (h) pencemaran (28\%); dan (i) pendangkalan atau hilangnya sungai/kolam/ danau (22\%); sedangkan 1 (satu) isu berdampak positif, yakni mengatasi kemiskinan (83\%). Kebijakan yang berpotensi menimbulkan dampak negatif ialah: peningkatan pertumbuhan ekonomi, pengembangan kawasan permukiman, dan prasaranasarana. Rencana struktur ruang dan rencana pola ruang yang terkait dengan kawasan budidaya berpotensi menimbulkan dampak negatif. Programprogram yang berpotensi menimbulkan dampak negatif ialah: program pengembangan hutan produksi, pertanian, perikanan, pertambangan, perindustrian, pariwisata, dan permukiman.

Cara mencegah atau mengurangi dampak negatif, yakni dengan mengintegrasikan nilai-nilai KLHS untuk pasal-pasal yang belum sepenuhnya memiliki nilai-nilai KLHS atau berpotensi sedang (36\%-50\%) sampai amat sangat besar (86\%-100\%) menimbulkan dampak negatif terhadap lingkungan hidup. Hasil evaluasi menunjukan bahwa 26 pasal perlu diperbaiki atau diberikan penambahan KRP untuk mencegah atau mengurangi dampak negatif terhadap lingkungan. Mencegah atau mengurangi dampak negatif ialah melibatkan masyarakat secara aktif dalam mengintegrasikan pembangunan berkelanjutan. Memberikan kesempatan yang sama kepada suluruh masyarakat untuk menikmati hasil-hasil hutan produksi, pertanian, perikanan, pertambangan, industri, pariwisata, dan permukiman, tanpa dibatasi oleh pengetahuan, ketrampilan, dan permodalan. Setiap masyarakat mendapat kesempatan yang sama dalam memperoleh pengetahuan, ketrampilan, dan permodalan untuk dapat memanfaatkan ruang dengan mengedepankan keberlanjutan hidup dalam proses pembangunan.

\section{DAFTAR PUSTAKA}

Anonimous. 2011. Pembangunan Berkelanjutan. http://id.wikipedia.org/wiki/Berkas

:Sustainable develpment.svg, diakses tanggal 2 September 2011. 
2011. Dokumen Raperda RTRW Kabupaten Bolaang Mongondow tahun 2011-2030. . 2011. Modul 1 KLHS Bangda Kemdagri. Daerah Membutuhkan Pembangunan Berkelanjutan. Kementrian Dalam Negeri. Jakarta.

. 2009. Peraturan Menteri Negara Lingkungan Hidup Nomor 27 Tahun 2009 Tentang Pedoman Pelaksanaan Kajian Lingkungan Hidup Strategis. 2008. Peraturan Pemerintah Republik Indonesia Nomor 26 Tahun 2008 Tentang Rencana Tata Ruang Wilayah Nasional. 2010. Surat Edaran Bersama (SEB) Menteri Dalam Negeri dan Menteri Negara Lingkungan Hidup Republik Indonesia dengan nomor: 660/5113/SJ dan nomor: 04/MENLH/12/2010.

. 2009. Undang-Undang Republik Indonesia Nomor 32 Tahun 2009 Tentang Perlindungan dan Pengelolaan Lingkungan Hidup. . 2007. Undang-Undang Republik Indonesia Nomor 26 tahun 2007 Tentang Penataan Ruang.

Arikunto Suharsimi. 2009. Manajemen Penelitian. Cetakan kesepuluh. Rineka Cipta. Jakarta

Atiek Koesrijanti, Laksmi Wijayanti, Soeryo Adiwibowo, Triarko Nurlambang, Chay Asdak. 2007. Kajian Lingkungan Hidup Strategis. Kementerian Negara Lingkungan Hidup. Jakarta.

Briffetta, C., Obbard J.P, and Mackee. 2003. Towards SEA for the developing nations of Asia. Environmental Impact Assessment Review. 23. 171-196 pp.
Department of Environmental Affairs and Tourism (DEAT) and CSIR. 2000. Strategic Environmental Assessment in South Africa: Guideline Document. Department of Environmental Affairs and Tourism, Pretoria.

Dusik J. 2009. KLHS Memfasilitasi Dialog dalam Proses Perencanaan. Pembelajaran dari prototipe-prototipe Penerapan KLHS. KLH. Jakarta.

KLH. 2010. Pendekatan Analitis Dalam Pelaksanaan KLHS. Modul C. ESP2. Yogyakarta.

ODPM. 2003. The UK Directive on Strategic Environmental Assessment: guidance for planning authorities. Office of the Deputy Prime Minister (ODPM). London.

Sadler, B. and Verheem, R. 1996. Strategic Environmental Assessment: Status, Challenges and Future Directions. Report no. 53. The Hague: Ministry of Housing, Physical Planning and Environment.

Sadler, B. 2005. Strategic Environmental Assessment at the Policy Level: Recent Progress, Current Status and Future Prospect. Editor. Ministry of The Environment, Czech Republic. Praha.

Thérivel, R.; Wilson, E.; Thompson, S.; Heaney, D. Pritchard, D. 1992. Strategic Environmental Assessment. Earthscan Publications Ltd, London. 
